\title{
Study on the Motif of Dream in Uygur Folk Dastan*
}

\author{
Aili Tuxunayi \\ School of Uyghur Language and Culture \\ Northwest Minzu University \\ Lanzhou, China 730030
}

\author{
Rousitaimujiang Abudouriyimu \\ School of Uyghur Language and Culture \\ Northwest Minzu University \\ Lanzhou, China 730030
}

\begin{abstract}
Dream is a physiological phenomenon, and also a psychological phenomenon, but the most important thing is that dream is a cultural phenomenon. It is an indispensable and important part of the Uighur folk Dastan. This paper focuses on the dream motif in the Uighur folk Dastan, and discusses the dream motifs and other forms of expression that appear in the Uighur folk Dastan.
\end{abstract}

\section{Keywords-Uygur Folk Dastan; Motif of Dream; culture}

\section{INTRODUCTION}

Dream is a cultural phenomenon. Dream is not only a physiological and psychological phenomenon of human beings, but also a cultural phenomenon. In ancient times, dreams began to be noticed by ancestors, and divination of dreams was the most common activity. Dreams not only appeared in the daily life of ancient people, but also described in literary works and oral art at that time. In the 11th century, the famous poet of the Karakhanid Empire, Yusup. Has. Hajip, recorded in "Wisdom to Happiness": "Divination dream is a kind of learning, and the diviner can enlighten you. If you dream while sleeping, Good diviners can make a sign based on your dreams." ${ }^{1}$ This shows that a thousand years ago, there were people in Uyghur society who specialized in "divine dreams." In addition, there is a large amount of content about "dreams" in Uighur folk Dastan. For example, "Dreaming of having a baby", "Dreaming of love", "Dreaming of Immortal", "Dreaming of Death" and so on. Almost every Dastan will have a dream motif. It can be seen that there is a close relationship between the Uyghur dream culture and the Uyghur folk literature. If dream is a cultural phenomenon, then the dream in Uyghur folk literature, which is an important part of Uyghur culture, is also an indispensable part of Uyghur culture.

"Motif can be a theme, a character, a storyline, or a style of words. Motif will appear in a literary work for many times and will be the main clue to unify the whole work. Motif may also be an image or a prototype. Motif is repeated in the work so that the whole work has a clear vein, and the

*This paper is a phased achievement of the Northwest Minzu University for postgraduate innovation project "Uygur Folk Love Dastan Research from the Perspective of the One Belt and Road

Initiative"(Yxm2017004 ) and National Social Science Fund "Uygur Folk oral poetics for the research"(15BZW196).

Doctoral student project of northwest minority literature research center "Study on the form of stories of uyghur folk dastan" (2018004B)

Yusup.Has. Hajip, Wisdom to Happiness, the Ethnic Publishing House, 1984.5, First edition: 901 (Uygur version) repeated appearance of motif can enhance the aesthetic appeal of the work. Motif may also be a symbol that represents a certain meaning in the work."2Motif is a cultural factor with inheritance in cultural inheritance. It is the smallest narrative unit and meaning unit in literary works. It is a recurring concept in literary works. These concepts include basic human behavior, spiritual phenomena and understanding of the real world. The role of the motif is to be able to be preserved in cultural heritage and to continue and replicate in later generations.

In Uygur folk literature, the range of motif is very rich and has a long history. These motifs are directly related to the Uyghur's regional life, history, production methods, customs, and religious beliefs ${ }^{3}$. "Dream" that appeared in the Uighur folk Dastan is an ancient motif. In the long-term creation, refinement and circulation of Uygur folk Dastan, dream motif formed a relatively fixed narrative modeand it repeated in different works, thus dream motif gradually becoming stylized. Driven by the cultural exchange of the Silk Road, dream motif has been continuously supplemented and developed, and its narrative model has become perfect. Dream motif is not only a simple narrative unit, but also based on a certain national culture, thus dream motif is closely related to the Uyghur national production labor, religious beliefs, lifestyle and national customs, and has rich cultural connotations and symbolic meanings.

Dream motif in Uighur folk Dastan can be divided into four forms:

\section{DREAMING OF HAVING A BABY}

This form is often associated with the motif of praying for a child. The motif of praying for a child is often found in Uyghur folk literature, especially in the Uighur folk Dastan. In this type of Dastan, the parents of the protagonist are usually very rich, but they are depressed and sorrow because they have no children. They prayed for a child by holding a ritual or other form of prayer and moved Allah to let the wife miraculously pregnant.Before the wife's pregnancy, her husband will have a magical dream. The person who divined the dream told him that he would become a father in the near future. In one variation of the Uygur folk Dastan, "Senuber ", the king of the Qin Nima Qin State, Khurshid, has no

\footnotetext{
Dasan Li, Methodology of Comparative Literature, Linking Publish, Taipei, 1982, First edition: 391

AhbuduvalyKeromu, Research on Uygur Folk Dastan, China Social Sciences Press, 2014.6: 235
} 
children and he feels very sad. He prayed to Allah to have a child. One day in a dream, he heard a voice from the sky saying that he would have a son. As a result, his youngest concubine was really pregnant and gave birth to a son. The king held a grand naming ceremony and named his son " Senuber ". 4

The first section of "The Book of DedeQorqut" has such a story: the great Ba Yan Del Khan of the Oghuz-Kepschak Union regularly greets the tribal leaders every year. In one year's banquet, he placed an order: set up white felt rooms to entertain the leader with sons and daughters. Set up red felt rooms to entertain the leader with daughters but no sons. Set up black felt rooms to entertain the leader without any children. Del Shel khan has no children. When he attended the banquet, he found that the waiter took him to the empty black felt room. He felt very humiliated and went away with anger. After that, Del Shel khan sent clothes and food to the hungry and cold according to his wife's instructions, and provided them with shelters. People who had been favored by Del Shel khan prayed to Allah and prayed that Allah could give Del Shel khan a child. One day, Del Sheikh had an auspicious dream. Later his wife became pregnant and gave birth to a boy nine months later ${ }^{5}$.

\section{A. Dreaming of Love}

Dreaming of love is one of the most common motifs in Uighur folk love Dastan. "Uighur love Dastan is the most popular, most infectious and widely spread type of folk literature." ${ }^{6}$ In Uighur folk love Dastan, the protagonist of the story grew up to an adult, dreaming of a beautiful girl he had never seen before. After waking up, he missed the girl in the dream day and night, he couldn't eat things and couldn't sleep and became thinner. Later, the protagonist, despited the blockade of his parents, embarked on the way of finding the girl in his dream. He went through many places, experienced a lot of suffering, and finally found the girl. In the end, he took her back to his country and succeeded to the throne, and lived happily with the girl he found.

"Prince Kemer and Beauty Samuel" is a typical love Dastan. This Dastan describes the love story between Prince Kemer and Beauty Samuel. When Prince Kemer grew up, he dreamed of a beautiful girl. From then on, he couldn't sleep and eat. The king was worried about his son's condition. He sent someone to ask what happened and knew that his son had dreamed a girl. The king found the man who can divine dreams, let him guess who the girl is in prince's dream, the divination said that the girl is Samuel, the only child of the Demon King, she lives in the city of the demon, who wants to find her must go 360 years' journey. After the king knew it, he urged the prince to change his mind, but the prince refused to give up so the king had to let him go. Prince

\footnotetext{
$4 \quad$ Abudurim·Rstymjan, Research on the Uygur Folk

Dastan:Senuber,Master Thesis ofMinzu University of China, 2014: 61

5 BanuKahraman: Korkut Ata, GonulYayincilik: 6

6 WusimanSimayi, Introduction to Uygur Folk Literature,

Xinjiang University Press, 2009.9: 646
}

Kemer began to travel to the city of the demon after bidding farewell to his parents.

UmayGney, a Turkish scholar, believes that in Turkish Dastan, there are several preconditions for the dreaming of love: (1) Special person, for example, a prince, a princess or a national hero, etc. (2) Special place, for example, gardens with four seasons, some holy land, etc. (3) The protagonist used a special wine glass and drank and fell asleep ${ }^{7}$. Senuber, the protagonist of the Uyghur folk Dastan "Senuber", is the only son of Khurshid, the king of Qin Nima Qin State. Senuber was very handsome and smart. When he was seven years old, the king entrusted him to a master who was proficient inQur'an. He completed his studies when he was ten years old. One day, Khurshid said to Senuber: "Son, you already have enough knowledge, now it is time to learn martial arts. After I die, this castle will be governed by you." The king built a forbidden court and selected 500 teenagers born on the same day as the prince. These teenagers and the prince lived together in the forbidden court to study martial arts. One day, Senuber and the teenagers played in the forbidden court and drank. Senuber was tired, he left his companions and went to the gazebo in the garden alone and fell asleep in bed. The prince had a strange dream. He dreamed that the daughter of King Farruh, who run the Bernstein Castle, floated down from the sky, sat beside him and talked with him intimately. After the conversation, the princess held a rose, and the fragrance of the rose floated into the prince's nose. Senuber woke up and found that it was just a dream. There is no one around him, let alone a princess. He was full of sorrow, sad and distressed, crying for the princess.

In some folk Dastan, not only the male protagonist dreams of his lover, but the female protagonist also dreams of her lover. For example, in the Uighur folk Dastan "Prince Nizamüddin and Princess Rennan", Princess Rennan, the female protagonist dreams of the male protagonist. Princess Rennan, the daughter of Sharm's King, is very beautiful, smart and kind. Many princes and nobles asked the king for the princess, but they were all rejected by Princess Rennan. Because Princess Rennan dreamed of a handsome young man and fell in love with him ${ }^{8}$.

It can be seen from the above stories that dreaming of love is an important plot of Uighur folk Dastan, especially in folk love Dastan. Dreaming of love reappears in love Dastan, and gradually forming a stylized feature, thus becoming an important part of Uighur folk love Dastan.

\section{B. Dreaming of Help}

Protagonists of the Uighur folk Dastan are not ordinary people. They embark on a journey in pursuit of love or friendship regardless of any difficulties. What they are pursuing is actually the wishes of the people. Therefore, the protagonists of the Uighur folk Dastancan always get magical help. Dreaming of help belongs to this magical help.

\footnotetext{
UmayGuney: ASIK TARZI SIIR GELENEGI VE RUYA MOTIFI, Ankara, 1986: 109

8 AhbuduresulyWomare, Selected Long Narrative Poems of Uygur Folk, Volksverlag Xinjiang, 1982.2: 399 (Uygur version)
} 
The protagonist has a magical dream when he/she encounters great obstacles or his/her life is at stake. In the magical dream, Allah will tell him/her how to get out of danger, solve difficulties, or when he/she wakes up, he finds what he/she needs.

For example, in "Ullriha and Amanukyan", there is a fragment describing that, Qin Ma Qin's King Khosro dreams of a parrot that can talk. When he woke up, he found that the parrot in his dream did not at his side, so he felt very painful. He has three sons, the eldest is Eskar Shah, the second one is Norton Shah, and the younger son is Amanukyan. The king asked the three princes to find the parrot in his dream, otherwise the three sons would not be qualified to be his son.The three princes are ready to travel, and the two brothers of Ai Amanukyan want to get back the parrot as soon as possible in order to get the reward of their father. They conspired to sneak up early and left Amanukyan far behind. After Amanukyan discovered this, he went to catch up with his brothers. On the third day, he caught up with his brothers at a fork road. On each intersection, there is a large stone with a number of striking words on it. The stone on the first intersection is engraved with "this toad is easy to go and easy to return." The stone on the second intersection is engraved with "this road is easy to go but difficult to return." The third intersection is engraved with "there is no return." Eskar Shah picked the first road, Norton Shah picked the second road and Amanukyan chose the last one. Amanukyan walked into the deserted. He walked for a long distance and felt very tired, he fell asleep on the side of the road. He dreamed of an old man who gave him directions and told him how to get the parrot". Another example is in "Prince Kemer and Beauty Samuel". The protagonist found the food he needed after he woke up. After falling in love with the girl in the dream, Prince Kemer took the road to the city of demon, regardless of his parents' dissuasion. He walked for a few months and the solid food prepared for the journey was eaten up. He did not give up and kept going. In the desert he was thirsty and hungry and fainted. He had a dream, dreaming of Hertzl, the saint. The saint told him how to find Samuel. Kemer woke up and found that there was a jar of yogurt and nine loaves of bread. He ate the bread and drank the yogurt, and continued on his journey ${ }^{10}$.

The motif dreaming of help adds some mystery to the folk Dastan. The protagonist of the folk Dastan has the power and courage beyond ordinary people. The protagonist of the folk Dastan is a means of expression of friendship and love, and the good wishes and pursuits of the people are usually embodied in the protagonist. Therefore, this mythical motif often appears in the Uighur folk Dastan.

\section{Dreaming of Omen}

Dreaming of omen add a mysterious veil on Uighur folk Dastan. In folk Dastan, almost every omenin dream appears in the form of a harbinger fromAllah or a phenomenon to the

AhbudukeromuReheman, Selected Long Poems of Uygur Folk, Volksverlag Xinjiang, 1981.1: 192

10 TusonayiAily, Research on Uygur Folk Dastan: Prince Kemer and Beauty Samuel, Master Thesis ofMinzu University of China,2014: 58 protagonist. There are two kinds of omens in Uighur folk Dastan. One is a dream that means auspiciousness, and the other is a dream that implies bad luck. The harbinger of dreams will be realized in the real world. These dreams have a strong predictive effect on the development and ending of the story.

Dreaming of omen has a long history in Uighur folk Dastan. In "Ughuz Khan", the oldest folk Dastan, contains such a fragment: Ughuz Khan has an old minister named Uruk Turk, his hair and beard are both white and he is very wise, just and kind. One day, he dreamed of a golden bow, which stretched from the east to the west. There were three silver arrows on the bow pointed directly to the north. After waking up, he told Ughuz Khanwhat he saw in his dream: "Oh, my Khan, may you reign forever! My Khan, may our laws be fair! May Allah's guidance in the dream make me foreseeing the best of your country! May the land you conquered be handed down from age to age" ${ }^{, 11}$. This is a typical dream of auspiciousness. In this story, the Minister explained the dream from Allah's guidance and then told Khan, emphasizing that the territory should be sealed to the prince on time. From the nature of the dream, this is a dream of auspiciousness and a dream with warning. Actually, in the monarchy society, the internal struggles of the royal family members often originate from territorial disputes and competition for the throne. The Minister's interpretation of the dream is a very good strategy for solving such problems.

The other omen is the sign of bad things. This kind of dream often indicates the occurrence of disasters. In"Alpames", oneof the Uighur folk Dastan, the protagonist Alpames was not in his hometown. One day he dreamed of a fierce vulture flying into his bed. Alpames made all his skills to drive it away but failed. Alpames was awakened from his dream and laden with anxiety. He worried that something bad had happened in his home so he rushed back to his hometown. When he returned home, he found that his hometown was occupied by the Kalemaks, and both his parents and sister became slaves. The Kalemaks leader was holding a wedding with his wife ${ }^{12}$. This is what his had dreamed before. The vultures represents the Kalemaks and their leaders.

"Yu Sufu and Ai Komti" is a Uighur hero Dastan. In this story, there is an Egypt king called Guzelesha. One day he had a dream: He put a jar of gold on his head and walked on the street, suddenly two tigers rushed to him, and the gold in the jar was scattered on the ground. Then there was a black bird wheeled in the sky, circling around above his head. Guzelesha was very scared after he woke up. He summoned the ministers in the court and asked them to explain his dream, but no one could explain that. Then a villager reported to the king that there was an old man lived in Qin Nima Qin who can explain his dream. Guzelesha immediately sent people to find this old man. The old Kanbair said: "The two tigers represent Yu Sufu and Ai

\footnotetext{
11 ShiminGeng, Ughuz, Khan, Volksverlag Xinjiang, 1980: 26

12 Editorial Committee of A Dictionary of Uygur Folk Literature, Uygur Folk Epic 3, Volksverlag Xinjiang, 2006: 191 (Uygur version)
} 
Komti, they will occupy your city. And the black bird represents the god of death, he wants your life." The king was very angry after he heard the old man's words and sent him to prison ${ }^{3}$. This is the dream of a tyrannical king in Dastan that indicates bad luck, and these signs would come true at last.

Dreaming of omen is just like a set of wireless signals for Uighur folk Dastan, it can give the protagonist some mystic instructions. The protagonist's action will verify these signs, and Dastan's ending will prove the accuracy of these signs. In conclusion, the motif of dream is a proof of the direct connection between the psychological activities of human dreams and the human subconscious. Dreams have their own cultural meanings and characteristics.

\section{CONCLUSION}

In a word, the mystery and the tragic sense of the dream are in line with the needs of the dual artistic opportunity of the uyghur people's religious acceptance and the internal nature of the creators of the folk dastan.Therefore, "dream motif" is so frequently used in the Uighur folk dastan, and so readily accepted by the general public.It is closely related to various cultural environments related to the creation, development and existence of the folk dastan, which constitutes the basis for the existence of the dream motif in the folk dastan and the deep implication of the meaning of the folk dastan.In the course of dastan's legacy, it must confront real life and real audiences.In response to the constantly developing reality, the "dream motif" in the long narrative poem is also indispensable. In addition to its function of raw potential at critical moments, its role of response can be reflected in two aspects here:One is that dreams and uygur mentality interweave together to ake up for the lack of reality the best expression.The second is that the dream and the aesthetic mechanism influenced by the religious concept combine together to become the treatment of grief.To sum up, "dream motif" is not only a bridge to play the prototype potential in the uygur folk narrative poetry, but also an artistic feature endowed by the tragic nature of real life and the contradiction between national psychology.

\section{REFERENCES}

[1] Editorial Committee of A Dictionary of Uygur Folk Literature, Uygur Folk Epic 1-5,Volksverlag Xinjiang, 2006

[2] Freud, Interpretation of Dreams, Shaanxi Normal University Press, 1984

[3] Yusup. Has. Hajip, Wisdom to Happiness, the Ethnic Publishing House, 1984

[4] JingwenZhong, An Introduction to Folk Literature, Higher Education Press, 2013.WAIS-III

[5] AhbuduvalyKeromu, Research on Uygur Folk Dastan, China Social Sciences Press, 2014.6

[6] AhbuduresulyWomare, Selected Long Narrative Poems of Uygur Folk, Volksverlag Xinjiang, 1982.2

13 Editorial Committee of A Dictionary of Uygur Folk Literature,

Uygur Folk Epic 5, Volksverlag Xinjiang, 2006: 16 (Uygur version)
[7] WusimanSimayi, Research on Uyghur Magic Story, Xinjiang University Press, 2006

[8] UmayGuney, Aski Tarzi Siir Gelenegi Ve Ruta Motifi, Ankara, 1986

[9] Fatma YILDIRMIS, Turk DestanlarindaRuya Motif, UluslararasiSosyalArastirmalarDergisi, 2016.9 